\title{
Corticosteroid therapy in patients with severe COVID-19
}

\author{
Terapia com corticosteroides em pacientes com COVID-19 grave \\ Terapia con corticosteroides en pacientes con COVID-19 grave
}

Received: 01/18/2021 | Reviewed: 01/21/2021 | Accept: 01/25/2021 | Published: 01/31/2021

Thiago Costa de Araújo Dantas

ORCID: https://orcid.org/0000-0002-1986-4883

Universidade Potiguar, Brazil

E-mail: thiagocostamed@gmail.com

Andriny Cunha Apoliano Gomes

ORCID: https://orcid.org/0000-0003-3396-1572

Universidade Potiguar, Brazil

E-mail: andrinycunhaapoliano@gmail.com

Ikaro Peixoto Correia Lima

ORCID: https://orcid.org/0000-0001-7599-2671 Universidade Potiguar, Brazil

E-mail: ikaropeixotao@hotmail.com

Beatriz Bispo Lucas

ORCID: https://orcid.org/0000-0002-7819-4453 Universidade Potiguar, Brazil

E-mail: bia_cearense@hotmail.com

Mateus Rodrigues de Aguiar

ORCID: https://orcid.org/0000-0001-7060-1205 Universidade Potiguar, Brazil

E-mail: mateusaguiar_@hotmail.com

Taiza Carvalho De Holanda Cavalcanti

ORCID: https://orcid.org/0000-0003-4164-9802 Universidade Potiguar, Brazil

E-mail: carvalhotaiza1@gmail.com

Francisco Irochima Pinheiro

ORCID: https://orcid.org/0000-0001-8879-3997

Universidade Potiguar, Brazil

E-mail: irochima@gmail.com

Amália Cinthia Meneses do Rêgo

ORCID: https://orcid.org/0000-0002-0575-3752

Universidade Potiguar, Brazil

E-mail: amaliarego@unp.br

Irami Araújo-Filho

ORCID: https://orcid.org/0000-0003-2471-7447

Universidade Potiguar, Brazil

E-mail: irami.filho@uol.com.br

\begin{abstract}
The world panorama of disseminating the new coronavirus SARS-CoV-2 is considered a pandemic by the World Health Organization (WHO) with the risk of complications due to the imbalance of immune responses. The present study evaluated whether the use of corticosteroids has scientifically proven efficacy in treating patients with the severe form of COVID-19. It was a cross-sectional and integrative literature review from December 2019 to November 2020 after researching the PubMed, Scopus, Embase, Web of Science, and Google Scholar databases. According to the studies analyzed, positive results of corticotherapy were observed in patients with SARS-CoV-2 in the severe form of the disease. It was concluded that steroids are not indicated in the mild form of COVID-19 unless they have other comorbidities, such as chronic obstructive pulmonary disease (COPD) or asthma. Glucocorticoid therapy is relevant in the severe form of SARS-CoV-2, with short-term management and low doses being beneficial. It reduces morbidity and mortality and the length of stay in the ICU.
\end{abstract}

Keywords: Coronavirus infections; COVID-19; SARS-CoV-2; Corticosteroids; Therapy; Therapeutics.

\section{Resumo}

O panorama mundial da disseminação do novo coronavírus SARS-CoV-2 é considerado uma pandemia pela Organização Mundial da Saúde (OMS) com risco de complicações devido ao desequilíbrio das respostas imunológicas. $\mathrm{O}$ presente estudo avaliou se o uso de corticosteroides tem eficácia cientificamente comprovada no tratamento de pacientes com a forma grave de COVID-19. Realizou-se uma revisão transversal e integrativa da literatura de dezembro de 2019 a novembro de 2020, após pesquisa nas bases de dados PubMed, Scopus, Embase, 
Web of Science e Google Scholar. De acordo com os estudos analisados, resultados positivos da corticoterapia foram observados em pacientes com SARS-CoV-2 na forma grave da doença. Concluiu-se que os esteroides não são indicados na forma leve de COVID-19, a menos que existam outras comorbidades, como doença pulmonar obstrutiva crônica (DPOC) ou asma. A terapia com glicocorticoides é relevante na forma grave da SARS-CoV-2, com o manejo de curto prazo e baixas doses sendo benéficos. Reduz a morbidade, mortalidade e o tempo de permanência na UTI.

Palavras-chave: Infecções por coronavírus; COVID-19; SARS-CoV-2; Corticosteroides; Terapia; Terapêutica.

\section{Resumen}

El panorama mundial de diseminación del nuevo coronavirus SARS-CoV-2 es considerado una pandemia por la Organización Mundial de la Salud (OMS) con riesgo de complicaciones por el desequilibrio de las respuestas inmunes. El presente estudio evaluó si el uso de corticosteroides tiene eficacia científicamente probada en el tratamiento de pacientes con la forma grave de COVID-19. Se realizó una revisión transversal e integradora de la literatura de diciembre de 2019 a noviembre de 2020 tras consultar las bases de datos PubMed, Scopus, Embase, Web of Science y Google Scholar. Según los estudios analizados, se observaron resultados positivos de la corticoterapia en pacientes con SARS-CoV-2 en la forma grave de la enfermedad. Se concluyó que los esteroides no están indicados para la forma leve de COVID-19 a menos que existan otras comorbilidades, como enfermedad pulmonar obstructiva crónica (EPOC) o asma. La terapia con glucocorticoides es relevante en la forma grave de SARS-CoV-2, siendo beneficioso el tratamiento a corto plazo y las dosis bajas. Reduce la morbilidad, mortalidad y el tiempo de estancia en la UCI.

Palabras clave: Infecciones por coronavirus, COVID-19, SARS-CoV-2, Corticosteroides, Terapia, Terapéutica.

\section{Introduction}

In November 2019, a series of patients with a new unexplained disease began to appear in Wuhan, China (Zha et al., 2020; Monte et al., 2020). The patients had pneumonia and quickly progressed to a serious condition. As the days passed, the number of infected people increased until it was discovered that it was a disease caused by a new type of coronavirus, called SARS-CoV-21 (Rizk et al., 2020; Bocchese et al., 2020).

The new virus had high contagious potential and spread to other countries and continents quickly and lethally. Thus, in March 2020, the World Health Organization (WHO) declared the disease caused by SARS-CoV-2, COVID-19, a pandemic (Yang et al., 2020; Goés et al., 2020; Li et al., 2020; Bocchese et al., 2020) (Figure 1).

Figure 1. Dissemination of SARS-Cov-2.

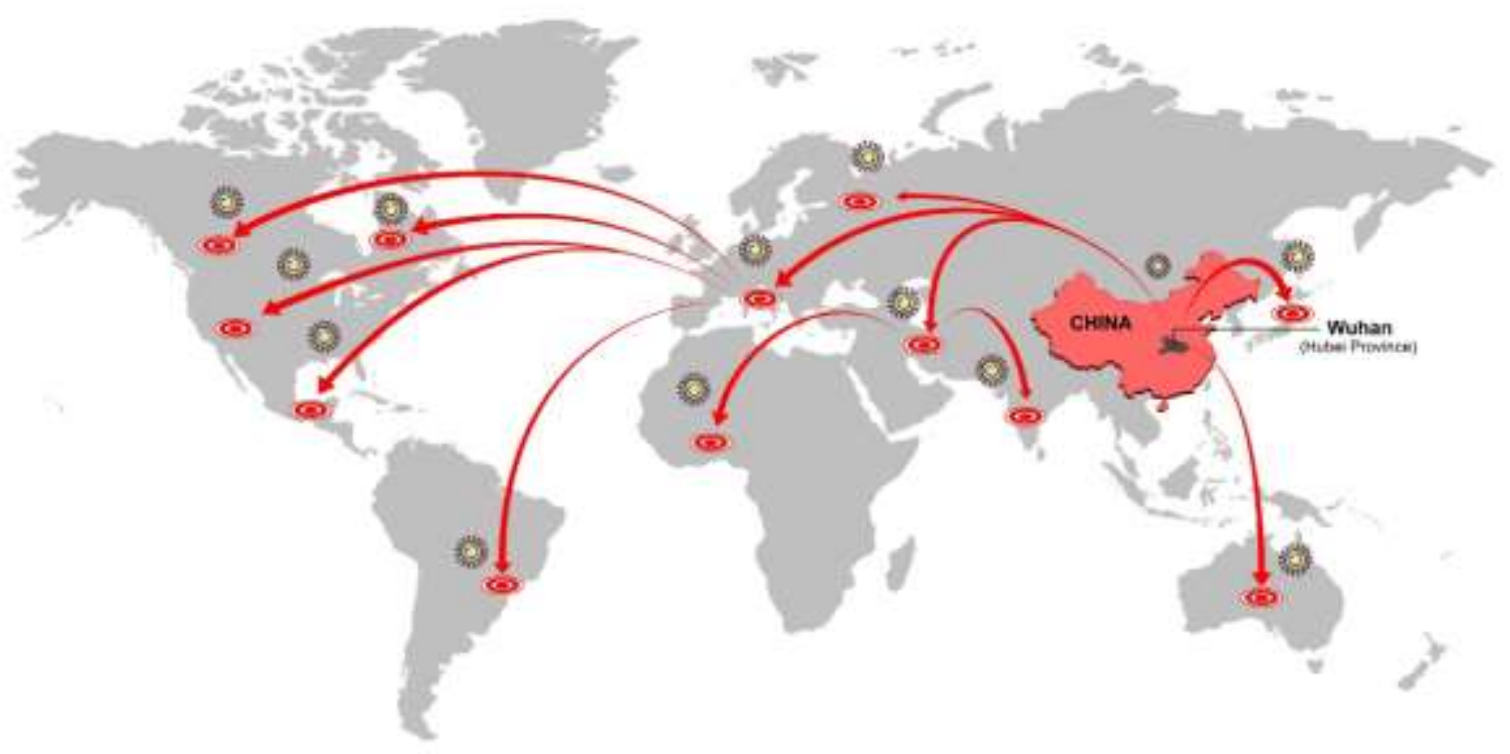


Figure 1 shows the spread of SARS-Cov-2 from the city of Wuhan, Province of Hubei in China to the rest of the world, progressively becoming a pandemic.

SARS-CoV-2 has a structure similar to that of SARS-CoV responsible for the SARS epidemic in 20031-3. In addition, the mortality caused by COVID-19 is similar to that of Middle East respiratory syndrome (MERS)1. However, the current disease includes myalgia, diarrhea, fever, and dry cough (Monte et al., 2020; Goés et al., 2020).

Severe cases range from mild pneumonia to acute respiratory distress syndrome (ARDS) and may progress to septic shock and multiple organ dysfunction syndrome (Yang et al., 2020; Li et al., 2020) (Figure 2).

Figure 2. Transmission of SARS-CoV-2 through the airways.

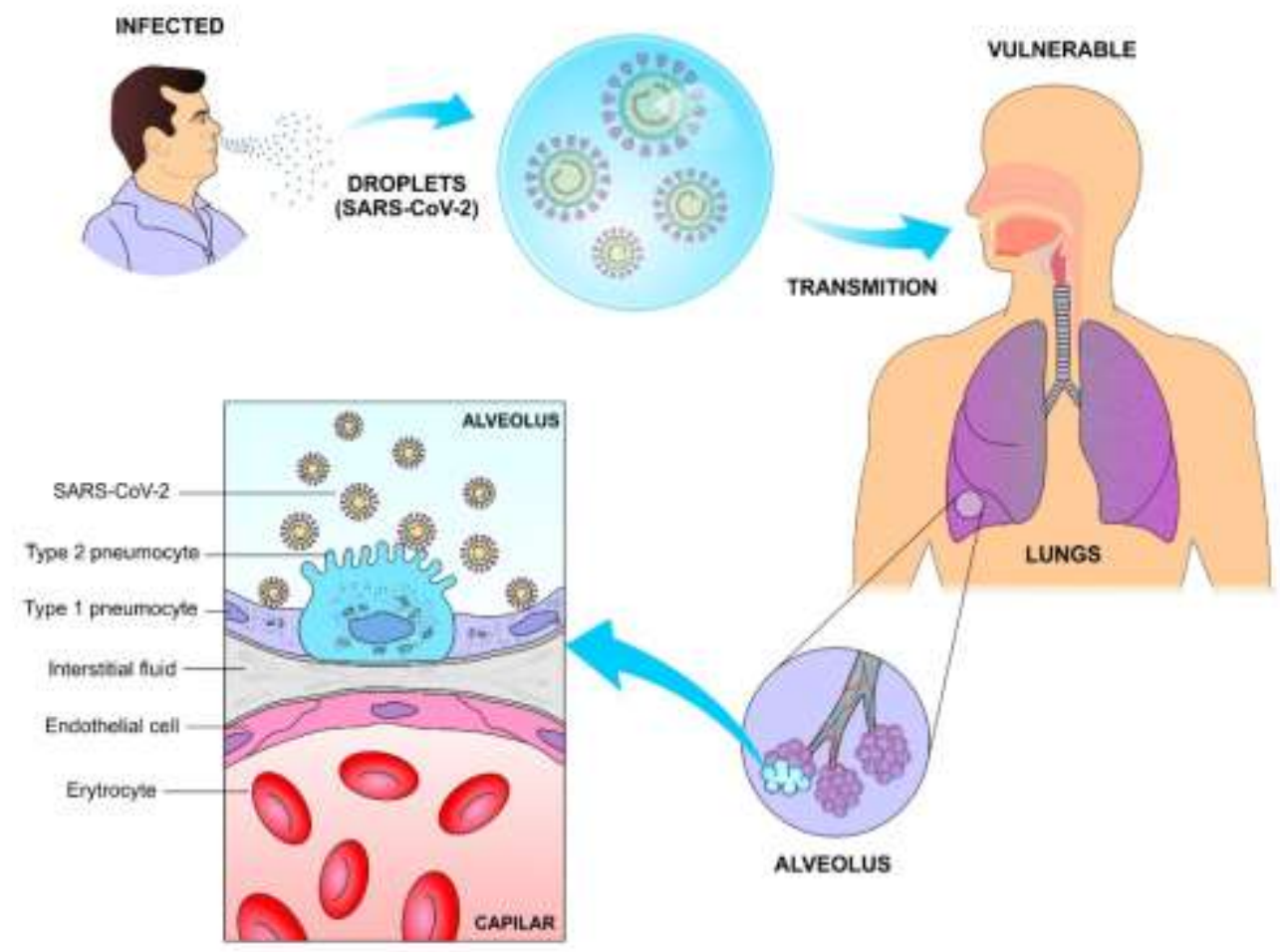

Source: Illustrations made by the authors themselves (2020).

In Figure 2, it is possible to observe the transmission of SARS-CoV-2 through the airways from a patient infected by COVI-19 to a healthy patient.

SARS-CoV-2 increases the levels of cytokines, C-reactive protein (CRP), interleukin-6 (IL-6), procalcitonin, and ferritin. The immune response imbalance is responsible for this "cytokine storm," severe lung injury, microthrombosis, and disseminated vascular coagulation (Bocchese et al., 2020; Zhao et al. 2020) (Figure 3). 
Figure 3. Systemic Inflammatory Response - Cytokines storm.

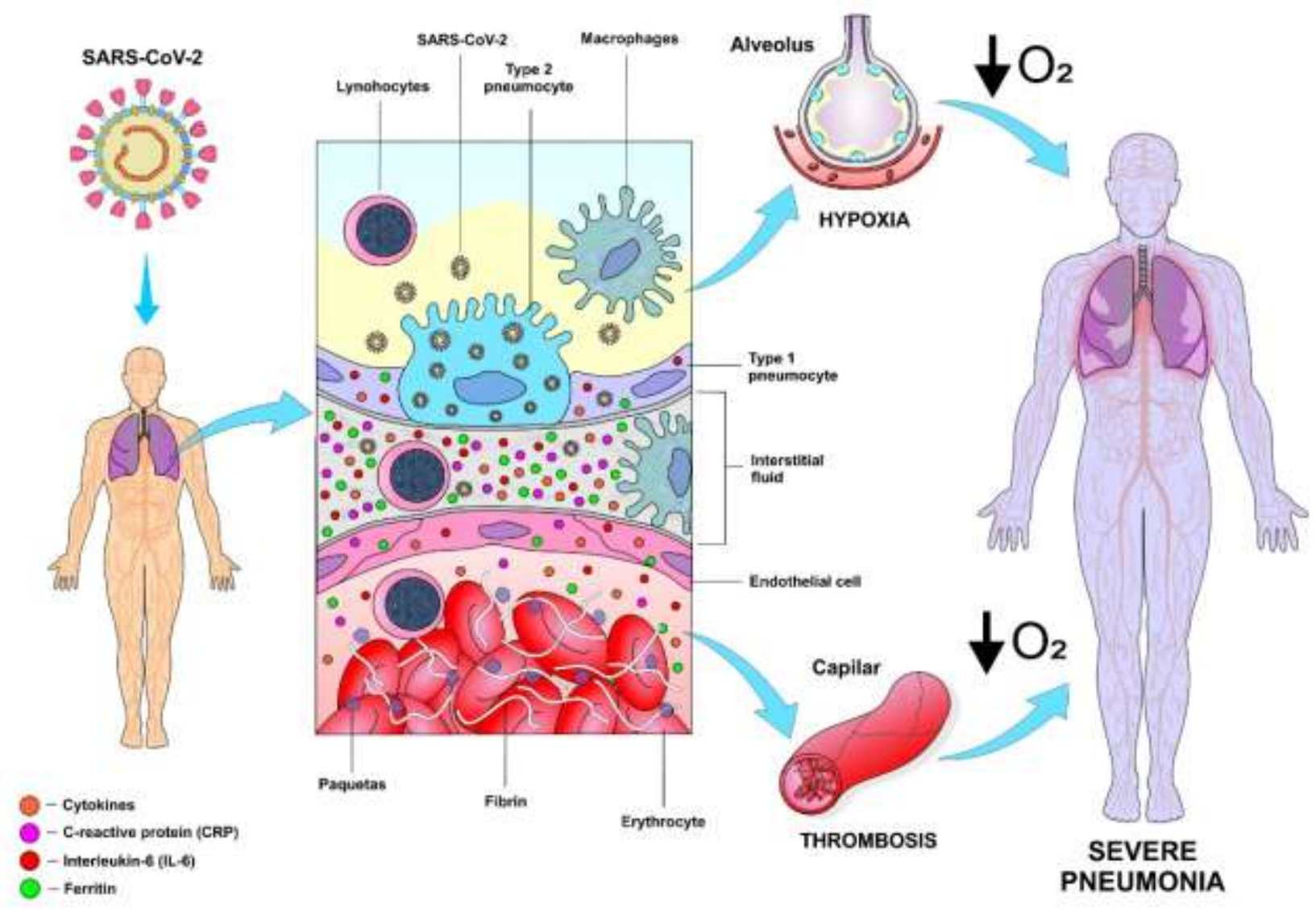

Source: Illustrations made by the authors themselves (2020).

In Figure 3, as a reaction to SARS-CoV-2 infection, an intense inflammatory response, known as Cytokines storm, is demonstrated by the production of mediators that amplify cellular damage (cytokines, C-reactive protein (CRP), interleukin- 6 (IL-6), procalcitonin, and ferritin).

As the condition progresses, severe pneumonia starts, followed by acute respiratory failure due to hypoxia and thrombotic events due to the systemic inflammatory process and hypercoagulability, resulting from endothelitis promoted by the viral infection.

The management of COVID-19 is based on supportive therapy consisting of fluid management, oxygen therapy, and mechanical ventilation (Li et al., 2020; Bocchese et al., 2020). Many drugs have been tested concerning pharmacotherapy due to the need for definitive treatment or cure given the rapid spread of the virus in the population. Thus, corticosteroids have emerged as an important therapeutic tool to be used (Bocchese et al., 2020; Yang et al., 2020; Goés et al., 2020).

Corticosteroids have an anti-inflammatory effect and are used in the adjuvant treatment of severe viral pneumonia, as they have a history of use in syndromes related to COVID-19, such as MERS, severe influenza, and community-acquired pneumonia, to combat target organ injuries produced by the invading pathogen (Zha et al., 2020; Zhao et al, 2020; Isidori, Pofi, Hasenmajer, Lenzi, \& Pivonello, 2020). 
The main mechanism of action is to inhibit proinflammatory genes that encode cytokines, cell adhesion molecules, inflammatory enzymes, and receptors to address the inflammatory process and restore homeostasis (Monte et al., 2020; Qin et al., 2020; Almeida \& Mendonca, 2020; Kolilekas et al., 2020) (Figure 4).

Figure 4. Corticosteroids - Mechanism of cellular action.

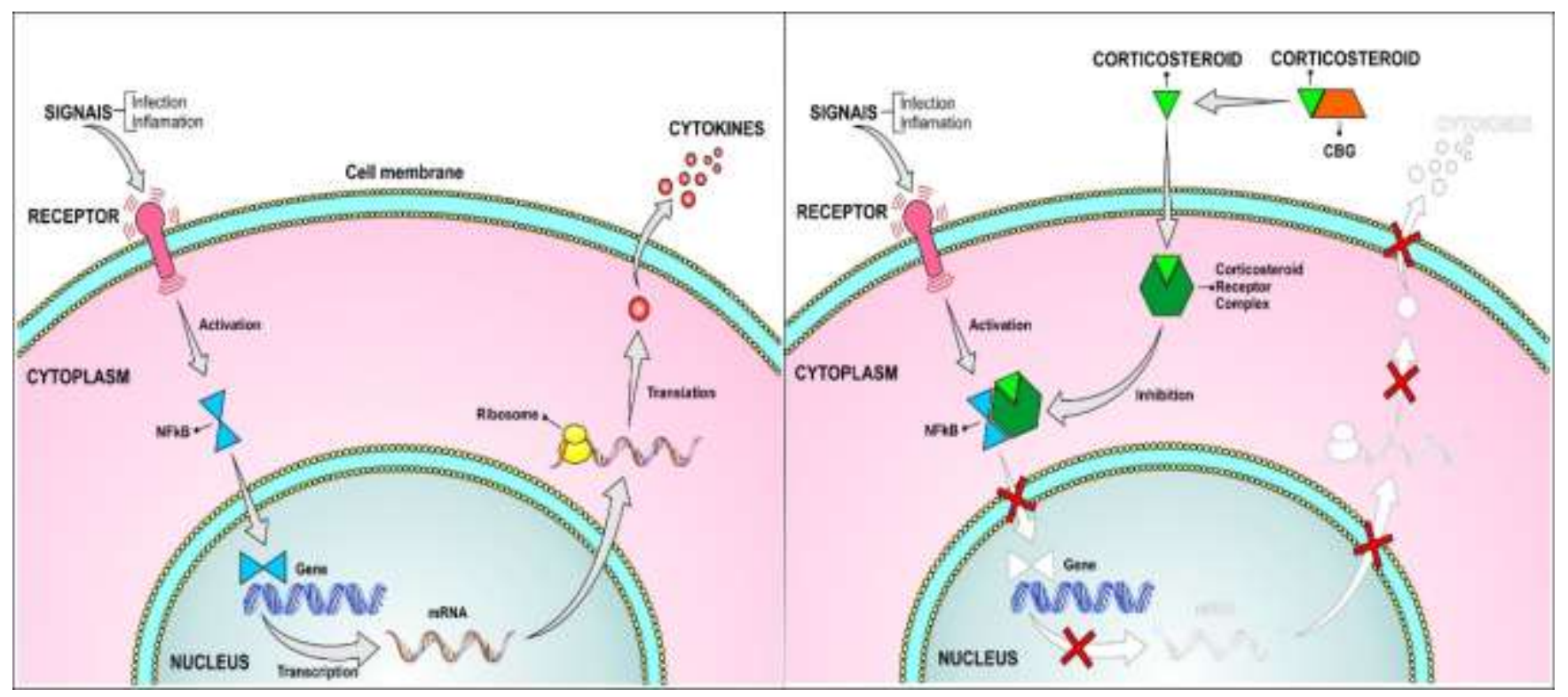

Source: Illustrations made by the authors themselves (2020).

According to what was described in the sentences above, in Figure 4, it is observed that corticosteroids are coupled to the cell membrane receptor, penetrating the cell and binding to the Nuclear factor-kB (NFkB). From their binding to NFkB, corticosteroids modulate the transcription and protein synthesis of cytokines through the intracellular inhibition of blocked $\mathrm{NFkB}$, acting directly in reducing the production of cytokines and, therefore, reducing the intensity of the systemic inflammatory response, observed in severe cases of COVID-19 (CBG- Corticosteroid-binding Globulin).

In this context, the objective of the present review was to evaluate the use of corticosteroid therapy in patients with COVID-19, to analyze clinical outcomes with an emphasis on severe cases of the disease, and to guide the performance of health professionals regarding the risks and benefits of this drug therapy based on scientifically validated literature data.

\section{Methodology}

It was an integrative literature review with a qualitative bias, gathering the synthesis of the most relevant studies for the topic under analysis (Pereira, Shitsuka, Pereira, \& Shitsuka, 2018). Indeed, an integrative literature review, based on descriptive analysis, results in deliberation and synthesis about the scientific knowledge already produced on the investigated topic, disseminating critical knowledge through reasoned practice, enabling the medical student/medical professional to make decision scientifically based to be applied in your daily activity in the face of the challenges presented. Aiming at the inclusion, or not, of studies in the scope of this review, means were used to delimit the relevant questions, as well as given the information to be extracted, defining, for this purpose, the guiding question, considered as the phase most relevant part of the whole process. Thus, the key question was asked: "Is the use of corticosteroids effective in the treatment of patients in the severe form of COVID-19?". The search for scientific articles indexed in the PubMed, Scopus, Embase, Web of Science and Google Scholar databases (classified with gray literature, as there is no peer review) using the health descriptors "Coronavirus Infections," "COVID-19", "SARS-CoV-2", “Corticosteroids," “Therapy," "Therapeutics," published between 2019 and 2020. 
The data search was conducted with a specific focus on the guiding question's response, being considered free access articles, full text, published in Portuguese, English, and Spanish, including data and guidelines from governmental bases of bodies linked to health management. Thus, given the small number of clinical studies related to COVID-19, 41 studies were selected, including articles of integrative review, systematic review, case report, randomized clinical trial, cohort study, and letters and opinion articles were discarded for not sources of scientific impact. Of the 41 documents, taking into account the topics necessary for the article and because of those that emerged from reading, nine studies were selected more intensely related to the use of corticosteroids in severe cases of COVID-19 pneumonia. The selection of studies was made blind by two researchers, with a third author in case of divergence between the inclusion or not of the research in the present review. After selecting the articles, the information extracted from them and their respective analyses were taken descriptively, with observation, description, and classification of the elements they brought, to gather the published knowledge on the theme chosen for this review. To extract the relevant data from the selected articles, a previously developed instrument by the authors was used to gather and synthesize the key information (corticotherapy, SARS-CoV-2, pneumonia), minimizing the risk of transcription errors and ensuring accuracy in checking information to serve as a record. The table data were consolidated as a precise tool, grouping the following information: order number of the article to better visualize it when reading the discussion, author(s), objective(s), and results.

\section{Results and Discussion}

After an exhaustive review of the included studies, the research achieved the following results, summarized in the following table (Table 1).

Table 1. Summary of the most relevant articles included in the review after peer review.

\begin{tabular}{|c|c|c|}
\hline Research & Objectives & Results \\
\hline $\begin{array}{l}\text { ZHA et al. } \\
\quad(2020)\end{array}$ & $\begin{array}{l}\text { To evaluate the } \\
\text { effectiveness of treatment } \\
\text { with corticosteroids in } \\
\text { patients with coronavirus } \\
2019 \text { (COVID-19). }\end{array}$ & $\begin{array}{l}\text { The use of corticosteroids was not associated with } \\
\text { a reduction in eliminating the virus, } \\
\text { hospitalization, or duration of symptoms. No } \\
\text { efficacy of the therapy was found in patients } \\
\text { without acute respiratory distress syndrome. }\end{array}$ \\
\hline $\begin{array}{l}\text { YANG, LIU, ZHOU, } \\
\text { ZHAO, ZHAO, \& LIU } \\
(\mathbf{2 0 2 0})\end{array}$ & $\begin{array}{l}\text { Detect the influence of } \\
\text { corticosteroids in patients } \\
\text { with coronavirus infection } \\
\text { (SARS-CoV-2). }\end{array}$ & $\begin{array}{l}\text { Critical patients were more likely to need } \\
\text { corticosteroid therapy. However, the treatment } \\
\text { brought higher mortality, longer stay, a higher rate } \\
\text { of bacterial infection. }\end{array}$ \\
\hline $\begin{array}{l}\text { QIN et al. } \\
\quad(2020)\end{array}$ & $\begin{array}{l}\text { Observe whether there is a } \\
\text { clinical therapeutic need for } \\
\text { the use of systemic } \\
\text { glucocorticoids in patients } \\
\text { with severe COVID- } 19 .\end{array}$ & $\begin{array}{l}\text { No positive evidence was found in the literature } \\
\text { for or against the use of systemic glucocorticoids } \\
\text { in patients with severe respiratory disease related } \\
\text { to COVID-19 or even in other types of severe } \\
\text { respiratory disease. }\end{array}$ \\
\hline
\end{tabular}




\begin{tabular}{|c|c|c|}
\hline $\begin{array}{l}\text { ZHOU et al. } \\
\qquad(2020)\end{array}$ & $\begin{array}{l}\text { Evaluate the benefits of } \\
\text { corticosteroid treatment in } \\
\text { critically ill patients with } \\
\text { severe pneumonia in 2019- } \\
\text { Sars-CoV2. }\end{array}$ & $\begin{array}{l}\text { The benefits of treatment with low doses of } \\
\text { corticosteroids in critically ill patients with 2019- } \\
\text { Sars-CoV2 have been demonstrated, although } \\
\text { there is no significant overall survival } \\
\text { improvement. }\end{array}$ \\
\hline $\begin{array}{l}\text { HALPIN, SINGH, \& } \\
\text { HADFIELD (2020) }\end{array}$ & $\begin{array}{l}\text { Assess whether the } \\
\text { administration of inhaled } \\
\text { steroids poses adverse risks } \\
\text { for acute respiratory } \\
\text { infections due to COVID- } \\
\text { 19, SARS, or MERS. }\end{array}$ & $\begin{array}{l}\text { There were no conclusive results on the use of } \\
\text { inhaled corticosteroids. The need to conduct } \\
\text { randomized studies to assess the benefits in the } \\
\text { treatment of COVID-19 in patients with and } \\
\text { without chronic respiratory disease was evidenced. }\end{array}$ \\
\hline $\begin{array}{l}\text { DAI et al. } \\
\quad(2020)\end{array}$ & $\begin{array}{l}\text { To present two serious } \\
\text { confirmed cases of COVID- } \\
19 \text { whose therapy was } \\
\text { performed with the use of } \\
\text { corticosteroids. }\end{array}$ & $\begin{array}{l}\text { The use of low to moderate doses of } \\
\text { corticosteroids is suggested, based on the } \\
\text { judgment of clinical courses, laboratory, and } \\
\text { radiological findings. Stratifying patients as to the } \\
\text { severity of the disease is fundamental to the } \\
\text { therapeutic choice. }\end{array}$ \\
\hline $\begin{array}{c}\text { PRESCOTT \& RICE } \\
(\mathbf{2 0 2 0})\end{array}$ & $\begin{array}{l}\text { To highlight the benefit of } \\
\text { corticosteroids for critically } \\
\text { ill patients with COVID-19, } \\
\text { it is clear that the exact } \\
\text { amount is still unclear. }\end{array}$ & $\begin{array}{l}\text { The use of corticosteroids is controversial, as there } \\
\text { are only results concerning previous respiratory } \\
\text { syndromes (SARS and MERS). The advantages of } \\
\text { use would be Harm reduction and early } \\
\text { inflammatory response. The disadvantages are } \\
\text { delayed viral clearance and avascular necrosis. }\end{array}$ \\
\hline $\begin{array}{l}\text { RECOVERY } \\
\text { COLLABORATIVE } \\
\text { GROUP }(2020)\end{array}$ & $\begin{array}{l}\text { Evidence that } \\
\text { glucocorticoids modulate } \\
\text { pulmonary inflammation } \\
\text { and, thus, prevent } \\
\text { respiratory failure and death. }\end{array}$ & $\begin{array}{l}\text { The use of dexamethasone in patients hospitalized } \\
\text { with Covid-19 reduced mortality among those who } \\
\text { received respiratory support, but not among those } \\
\text { who were not on mechanical ventilation. }\end{array}$ \\
\hline $\begin{array}{c}\text { SANTOS \& FERRAZ } \\
(\mathbf{2 0 2 0})\end{array}$ & $\begin{array}{l}\text { Compile the most important } \\
\text { works with the theme of } \\
\text { therapies against } \\
\text { coronavirus. }\end{array}$ & $\begin{array}{l}\text { The use of antibiotics and corticosteroids should } \\
\text { be evaluated with caution. Hydroxychloroquine, } \\
\text { heparin, and ibuprofen are widely used agents in } \\
\text { the treatment of Covid-19. However, there are no } \\
\text { studies that prove the effectiveness of the drugs } \\
\text { mentioned. }\end{array}$ \\
\hline
\end{tabular}

Source: Authors.

The disease caused by the new coronavirus is defined by the clinical picture in the mild, moderate, and severe form of the disease, consisting of manifestations ranging from pneumonia to severe acute respiratory distress syndrome (ARDS), 
septic shock, multiple organ dysfunction syndromes, causing diffuse alveolar damage and an uncontrolled inflammatory state (Zha et al., 2020; Isidori et al., 2020). According to Zhou et al. (2020), the average number of patients with SARS-CoV-2 infection who progress to a severe or fatal level is $3-13 \%$.

The discussion on the use of glucocorticoids in COVID-19 is based on the clinical picture. Potential advantages of steroid use include reducing immunopathological damage and alleviating the effects of the proinflammatory response (cytokine storm), as the uncontrolled inflammatory state is prevalent in patients with COVID-19 and contributes to multiple failures of organs (Kolilekas et al., 2020; Zhou et al., 2020).

The disadvantages include delayed viral clearance and the adverse effects of avascular necrosis, diabetes, and psychosis previously shown in the approach of patients with SARS-CoV and MERS-CoV (Goés et al., 2020; Kolilekas et al., 2020).

According to Yang et al. (2020), the use of corticosteroids is not indicated in the mild form of SARS-CoV-2. However, according to Mendes et al., the indication becomes plausible in the presence of chronic lung diseases, asthma, COPD, or septic shock (Mendes, Mergulhão, Froes, Paiva, \& Gouveia, 2020). Corticosteroids reduce the risk of exacerbating the pathologies above since, according to Halpin, Singh and Hadfield (2020), approximately 40-60\% of COPD and up to 80\% of asthma exacerbations are viral infections (Halpin et al., 2020).

It is currently to use corticosteroid therapy in the presence of a moderate and severe form of SARS-CoV-2 without the suspicion of active bacterial infection 10-14 days after the beginning of the disease, sepsis, or septic shock (Wu et al., 2020; Dai et al., 2020).

According to Dai et al. (2020), this indication makes the reasonable and appropriate use of corticosteroids by attenuating lung injury related to cytokines, reducing the exuberant clinical picture, and inhibiting the evolution to sepsis.

Zhou et al. (2020) evaluated a group of patients hospitalized in the ICU and concluded that corticosteroid therapy could increase oxygen saturation, corroborating the improvement of the clinical picture of hypoxia.

In this context, the efficacy, already proven, of the use of glucocorticoids in patients with moderate and severe COVID-19 has become evident (Dai et al., 2020; Dequin et al., 2020; Tan, Hong, Saha, Murphy, \& Hui, 2020).

Dequin et al. (2020) concluded that small doses of hydrocortisone in treating patients with severe COVID-19 pneumonia when compared to placebo were ineffective and did not reduce mortality or the need for respiratory support.

On the other hand, Prescott and Rice (2020) observed that the benefits of using corticosteroids, reduced mortality, and the need for mechanical ventilation were the same for both groups, dexamethasone and hydrocortisone, even though the necessary dosage of hydrocortisone is still not possible.

For the beneficial use of corticosteroids, it is worth mentioning that it is based on the medication's time and dose (Zhou et al., 2020). Dai et al. (2020) in the search for the recommended dose, emphasized that it should be low to moderate (less than or equal to $0.5-1 \mathrm{mg} / \mathrm{kg}$ per day of methylprednisolone or equivalent), and the duration should be short ( $<7$ days). The lower dose, associated with monitoring the medication's adverse effects, makes this therapy effective in the clinical management of critically ill patients with COVID-19 (Prescott \& Rice, 2020).

With regard to glucocorticoid dosage data, recent studies state that doses vary between the type of medication used: dexamethasone $20 \mathrm{mg} / \mathrm{day}$ for 5 days followed by $10 \mathrm{mg}$ /day for 5 days (CoDEX trial); hydrocortisone $200 \mathrm{mg} / \mathrm{day}$ for 4-7 days followed by $100 \mathrm{mg} /$ day for 2-4 days and then $50 \mathrm{mg} /$ day for 2-3 days (Tomazini et al., 2020).

Several studies discuss the use of glucocorticoids in the presence of COVID-19 and viral pneumonia (Brasil, Ministério da Saúde, 2020). The pathophysiological damage of severe COVID-19 is determined by an acute pneumonic process, with inflammatory damage to several target organs in viral pneumonia, as this pathology is responsible for causing, according to Selvaraj, Dapaah-Afriyie, Finn and Flanigan (2020), an inflammatory response in the clinical course of a patient 
with SARS-CoV-220. In this study, the use of early dexamethasone in the short term stands out and is responsible for reducing the levels of CRP and inflammation.

Accordingly, the CoDEX study proved that the benefit after the 7th day of the disease course with corticosteroid therapy reduced mortality (Tomazini et al., 2020). Therefore, corticosteroids have an excellent inhibitory effect on inflammatory factors and are often used as an additional treatment for viral pneumonia (Liu et al., 2020). Other studies have shown better clinical outcomes in cases of severe pneumonia (Recovery Collaborative Group, 2020; Falavigna et al., 2020).

The CoDEX study consisted of a randomized clinical trial with 299 patients in 41 ICU beds with moderate or severe ARDS due to COVID-19 using high-dose open-label dexamethasone $(20 \mathrm{mg} /$ day for five days, followed by $10 \mathrm{mg} /$ day for five days) compared to usual care (Tomazini et al., 2020). The use of corticosteroids associated with standard treatment effectively reduces the number of days in the ICU and the prolonged need for mechanical ventilation.

In the same vein, the RECOVERY study's (2020) expansion demonstrated the effective action of corticosteroids, even when the basal mortality rate was high. In summary, dexamethasone reduced both SARS-CoV-2-related ventilatory complications and mortality in patients on mechanical ventilation.

On the other hand, Dequin et al. (2020) stated no significant reduction in death or continued ventilatory support in patients who used hydrocortisone compared to placebo. However, this study was stopped early, which is a critical bias regarding the outcome of the primary outcome.

According to the present review, there are multiple complications due to the use of glucocorticoids, profound immunosuppression, the emergence of severe viral, bacterial, and fungal infections, as well as osteonecrosis of the femoral head and psychosis, which can occur with prolonged therapy and high doses of glucocorticoid (Santos \& Ferraz, 2020; Tang et al., 2020).

Based on the above, since it is a delicate and controversial topic, the World Health Organization's provisional guidelines on the clinical management of COVID-19 advise against the use of systemic corticosteroids outside clinical trials and especially in mild cases of the disease (Prescott \& Rice, 2020; Liu et al., 2020).

However, after finding a positive response in randomized controlled clinical studies, the use of corticosteroids for a short duration, in low doses, demonstrated efficacy in inhibiting the systemic inflammatory response and reducing the length of ICU stay in severe forms of COVID-19 (Tang et al., 2020; Zhang, Lee, Ang, Leo, \& Young, 2020).

\section{Conclusion}

In conclusion, the present study addressed the management of corticosteroid therapy in the severe form of SARSCoV-2, COVID-19, a pathology with high contagious power and fatal complications. The analysis of the selected studies aimed at better guidance for health professionals who are at the forefront in combating the pandemic. The present review showed that patients with the severe form of SARS-CoV-2 were the ones who most benefited from the use of glucocorticoids used cautiously, for a short period, and in low doses.

The authors suggest that due to the importance of corticosteroid therapy in the prognosis of patients with severe pneumonia caused by SARS-CoV-2, new studies aim to create new protocols to assess safety, efficacy and interference in viral replication related to doses and time of therapy.

\section{References}

Almeida, M. Q., \& Mendonca, B. B. (2020). Adrenal Insufficiency and Glucocorticoid Use During the COVID-19 Pandemic. Clinics, 75 , e2022. https://doi.org/10.6061/clinics/2020/e2022. 
Bocchese, N. V., Dávila, N. G., Rodrigues, M. B. M., Araújo-Neto, I., Costa, M. O., Barbalho, D. M. G., Rêgo, A. C. M., \& Araújo-Filho, I. (2020). COVID19 and Liver Injury: Hepatology Perspectives. Journal of Clinical Gastroenterology and Treatment, 6(074), 1-5. https://doi.org/10.23937/2469-584X/1510074.

Bocchese, N. V., Dávila, N. G., Rodrigues, M. B. M., Monte, R. R. L., Melo, R. C., Rêgo, A. C. M., \& Araújo-Filho, I. (2020). Covid-19: Gastroenterology Perspectives. Journal of clinical gastroenterology and treatment, 6(075), 1-8. https://doi.org/10.23937/2469-584X/1510075.

Ministério da Saúde. Informe diário de evidências - Covid-19 (2020). Secretaria de Ciência, Tecnologia, Inovação e Insumos Estratégicos em Saúde. Brasília, 44, 1-26, http://bvsms.saude.gov.br/bvs/publicacoes/Politica_Portugues.pdf

Dai, J., Xiong, Y., Li, H., Qian, Y., Xu, Y., Xu, Q., Yan, X., \& Tang, J. (2020). Corticosteroid treatment in severe COVID-19 pneumonia: two cases and literature review. Clinical rheumatology, 39(7), 2031-2037. https://doi.org/10.1007/s10067-020-05172-7.

Dequin, P. F., Heming, N., Meziani, F., Plantefève, G., Voiriot, G., Badié, J., François, B., Aubron, C., Ricard, J. D., Ehrmann, S., Jouan, Y., Guillon, A., Leclerc, M., Coffre, C., Bourgoin, H., Lengellé, C., Caille-Fénérol, C., Tavernier, E., Zohar, S., \& Giraudeau, B. CAPE COVID Trial Group and the CRICSTriGGERSep Network (2020). Effect of Hydrocortisone on 21-Day Mortality or Respiratory Support Among Critically Ill Patients With COVID-19: A Randomized Clinical Trial. JAMA, 324(13), 1298-1306. https://doi.org/10.1001/jama.2020.16761.

Falavigna, M., Colpani, V., Stein, C., Azevedo, L. C. P., Bagattin, A. M., Brito, G. V., Chatkin, J. M., Cimerman, S., Corradi, M. F. D., Cunha, C. A., Medeiros, F. C., Junior, H. A. O., Fritcher, L. G., Gazzana, M. B., Gräf, D. D., Marra, L. P., Matuoka, J. Y., Nunes, M. S., Pachito, D. V., Pagano, C. G. M., Parreira, P. C. S., Riera, R., Junior, A. S., Tavares, B. M., Zavascki, A. P., Rosa, R. G., \& Dal-Pizzol, F. (2020). Diretrizes para o tratamento farmacológico da COVID-19. Consenso da Associação de Medicina Intensiva Brasileira, da Sociedade Brasileira de Infectologia e da Sociedade Brasileira de Pneumologia e Tisiologia. Revista Brasileira de Terapia Intensiva, 32(2), 166-196. https://doi.org/10.5935/0103-507x.20200039.

Goés, A. B. M., Cardoso, B. B., Tavares, F. A. F., Monte, R. R. L., Melo, R. C., Araújo-Neto, I., Pinheiro, R. S. E., Rêgo, A. C. M., \& Araújo-Filho, I. (2020). COVID-19 and Nervous System: Under Estimated Clinical and Prognostic Aspects. International journal of neurology and neurotherapy, 7(100), 1-7. https://doi.org/10.23937/2378-3001/1410100.

Halpin, D., Singh, D., \& Hadfield, R. M. (2020). Inhaled corticosteroids and COVID-19: a systematic review and clinical perspective. The European respiratory journal, 55(5), 2001009. https://doi.org/10.1183/13993003.01009-2020.

Isidori, A. M., Pofi, R., Hasenmajer, V., Lenzi, A., \& Pivonello, R. (2020). Use of glucocorticoids in patients with adrenal insufficiency and COVID-19 infection. The lancet. Diabetes \& Endocrinology, 8(6), 472-473. https://doi.org/10.1016/S2213-8587(20)30149-2.

Kolilekas, L., Loverdos, K., Giannakaki, S., Vlassi, L., Levounets, A., Zervas, E., \& Gaga, M. (2020). Can steroids reverse the severe COVID-19 induced "cytokine storm"?. Journal of medical virology, 92(11), 2866-2869. https://doi.org/10.1002/jmv.26165.

Li, H., Chen, C., Hu, F., Wang, J., Zhao, Q., Gale, R. P., \& Liang, Y. (2020). Impact of corticosteroid therapy on outcomes of persons with SARS-CoV-2, SARS-CoV, or MERS-CoV infection: a systematic review and meta-analysis. Leukemia, 34(6), 1503-1511. https://doi.org/10.1038/s41375-020-0848-3.

Liu, J., Zhang, S., Dong, X., Li, Z., Xu, Q., Feng, H., Cai, J., Huang, S., Guo, J., Zhang, L., Chen, Y., Zhu, W., Du, H., Liu, Y., Wang, T., Chen, L., Wen, Z., Annane, D., Qu, J., \& Chen, D. (2020). Corticosteroid treatment in severe COVID-19 patients with acute respiratory distress syndrome. The Journal of clinical investigation, 130(12), 6417-6428. https://doi.org/10.1172/JCI140617.

Mendes, J. J., Mergulhão, P., Froes, F., Paiva, J. A., \& Gouveia, J. (2020). Recomendações da Sociedade Portuguesa de Cuidados Intensivos e Grupo de Infeção e Sépsis para a abordagem do COVID-19 em medicina intensiva. Revista Brasileira de Terapia Intensiva, 32(1), 2-10. https://doi.org/10.5935/0103507x.20200002.

Monte, R. R. L., Tavares, F. A. F., Cardoso, B. B., Goes, A. B. M., Silva, T. C. L., Silva, B. O., Araújo, Y. S. M., Rêgo, A. C. M., \& Araújo-Filho, I. (2020). Covid-19 Pandemic and Health Professionals: Practical Approaches. International Journal of Critical Care and Emergency Medicine, 6(108), 1-9. https://doi.org/10.23937/2474-3674/1510108.

Pereira, A. S., Shitsuka, D. M., Pereira, F. J., \& Shitsuka, R. (2018). Metodologia da pesquisa científica. [e-book]. Santa Maria. Ed. UAB/NTE/UFSM. https://repositorio.ufsm.br/bitstream/handle/1/15824/Lic_Computacao_Metodologia-Pesquisa-Cientifica.pdf?sequence=1. Este e-book é gratuito.

Prescott, H. C., \& Rice, T. W. (2020). Corticosteroids in COVID-19 ARDS: Evidence and Hope During the Pandemic. JAMA, 324(13), 1292-1295. https://doi.org/10.1001/jama.2020.16747.

Qin, Y. Y., Zhou, Y. H., Lu, Y. Q., Sun, F., Yang, S., Harypursat, V., \& Chen, Y. K. (2020). Effectiveness of glucocorticoid therapy in patients with severe coronavirus disease 2019: protocol of a randomized controlled trial. Chinese medical journal, 133(9), 1080-1086. https://doi.org/10.1097/CM9.0000000000000791.

Recovery Collaborative Group, Horby, P., Lim, W. S., Emberson, J. R., Mafham, M., Bell, J. L., Linsell, L., Staplin, N., Brightling, C., Ustianowski, A., Elmahi, E., Prudon, B., Green, C., Felton, T., Chadwick, D., Rege, K., Fegan, C., Chappell, L. C., Faust, S. N., Jaki, T., \& Landray, M. J. (2020). Dexamethasone in Hospitalized Patients with Covid-19 - Preliminary Report. The New England journal of medicine, NEJMoa2021436. Advance online publication. https://doi.org/10.1056/NEJMoa2021436.

Rizk, J. G., Kalantar-Zadeh, K., Mehra, M. R., Lavie, C. J., Rizk, Y., \& Forthal, D. N. (2020). Pharmaco-Immunomodulatory Therapy in COVID-19. Drugs, 80(13), 1267-1292. https://doi.org/10.1007/s40265-020-01367-Z.

Santos, F. S., \& Ferraz, R. R. N. (2020). Tratamentos para COVID-19: síntese de evidências. International Journal of Health Managemen Review. (2020). 6(1), 1-9. https://ijhmreview.org/ijhmreview/article/viewFile/200/135.

Selvaraj, V., Dapaah-Afriyie, K., Finn, A., \& Flanigan, T. P. (2020). Short-Term Dexamethasone in Sars-CoV-2 Patients. Rhode Island medical journal (2013), 103(6), 39-43. 
Research, Society and Development, v. 10, n. 1, e58910112114, 2021 (CC BY 4.0) | ISSN 2525-3409 | DOI: http://dx.doi.org/10.33448/rsd-v10i1.12114

Tan, S., Hong, C. C., Saha, S., Murphy, D., \& Hui, J. H. (2020). Medications in COVID-19 patients: summarizing the current literature from an orthopaedic perspective. International orthopaedics, 44(8), 1599-1603. https://doi.org/10.1007/s00264-020-04643-5.

Tang, C., Wang, Y., Lv, H., Guan, Z., \& Gu, J. (2020). Caution against corticosteroid-based COVID-19 treatment. Lancet (London, England), 395(10239), 1759-1760. https://doi.org/10.1016/S0140-6736(20)30749-2.

Tomazini, B. M., Maia, I. S., Cavalcanti, A. B., Berwanger, O., Rosa, R. G., Veiga, V. C., Avezum, A., Lopes, R. D., Bueno, F. R., Silva, M., Baldassare, F. P., Costa, E., Moura, R., Honorato, M. O., Costa, A. N., Damiani, L. P., Lisboa, T., Kawano-Dourado, L., Zampieri, F. G., \& Olivato, G. B. Coalition COVID19 Brazil III Investigators (2020). Effect of Dexamethasone on Days Alive and Ventilator-Free in Patients With Moderate or Severe Acute Respiratory Distress Syndrome and COVID-19: The CoDEX Randomized Clinical Trial. JAMA, 324(13), 1307-1316. https://doi.org/10.1001/jama.2020.17021 .

Yang, Z., Liu, J., Zhou, Y., Zhao, X., Zhao, Q., \& Liu, J. (2020). The effect of corticosteroid treatment on patients with coronavirus infection: a systematic review and meta-analysis. The Journal of infection, 81(1), e13-e20. https://doi.org/10.1016/j.jinf.2020.03.062.

Wu, J., Huang, J., Zhu, G., Liu, Y., Xiao, H., Zhou, Q., Si, X., Yi, H., Wang, C., Yang, D., Chen, S., Liu, X., Liu, Z., Wang, Q., Lv, Q., Huang, Y., Yu, Y., Guan, X., Li, Y., Nirantharakumar, K., \& Xiao, H. (2020). Systemic Corticosteroids and Mortality in Severe and Critical COVID-19 Patients in Wuhan, China. The Journal of clinical endocrinology and metabolism, 105(12), 627. https://doi.org/10.1210/clinem/dgaa627.

Zha, L., Li, S., Pan, L., Tefsen, B., Li, Y., French, N., Chen, L., Yang, G., \& Villanueva, E. V. (2020). Corticosteroid treatment of patients with coronavirus disease 2019 (COVID-19). The Medical journal of Australia, 212(9), 416-420. https://doi.org/10.5694/mja2.50577.

Zhang, J., Lee, K. S., Ang, L. W., Leo, Y. S., \& Young, B. E. (2020). Risk Factors for Severe Disease and Efficacy of Treatment in Patients Infected With COVID-19: A Systematic Review, Meta-Analysis, and Meta-Regression Analysis. Clinical infectious diseases: an official publication of the Infectious Diseases Society of America, 71(16), 2199-2206. https://doi.org/10.1093/cid/ciaa576.

Zhao, J. P., Hu, Y., Du, R. H., Chen, Z. S., Jin, Y., Zhou, M., Zhang, J., Qu, J. M., \& Cao, B. (2020). Zhonghua jie he he hu xi za zhi = Zhonghua jiehe he huxi zazhi = Chinese journal of tuberculosis and respiratory diseases, 43(0), E007. Advance online publication. https://doi.org/10.3760/cma.j.issn.10010939.2020.0007.

Zhou, W., Liu, Y., Tian, D., Wang, C., Wang, S., Cheng, J., Hu, M., Fang, M., \& Gao, Y. (2020). Potential benefits of precise corticosteroids therapy for severe 2019-nCoV pneumonia. Signal transduction and targeted therapy, 5(1), 18. https://doi.org/10.1038/s41392-020-0127-9. 